\title{
perifèria
}

Número 7, Diciembre 2007

www. periferia. name

\section{Water tanks as ecosystems. Local ecosystemic perception for integral management of water tanks in Tamil Nadu, South I ndia}

\author{
Pere Ariza ${ }^{1}$, Elena Galán, Tarik Serrano, Victoria Reyes-García - Laboratori
}

d'Etnoecologia $^{2}$ - UAB

\section{Resumen}

Los tanques de agua (water tanks) ofrecen desde hace siglos soluciones en el Sur de la India a los problemas derivados de la escasez de agua. Son un sistema tradicional de recogida de agua de lluvia ampliamente distribuido por este territorio, que permite una potencial gestión de los propios recursos a nivel local, descentralizada y participativa. Aunque la principal función de los tanques de agua es la irrigación, existen muchos otros usos, funciones y recursos naturales asociados a ellos que permiten la inclusión de muchos más actores de la comunidad, aparte de aquellos agricultores que aprovechan la irrigación. Los tanques de agua configuran además una variedad de paisaje y biodiversidad, creando una valiosa heterogeneidad territorial. La complejidad de este ecosistema debe ser gestionada con una perspectiva integral que considere todos los elementos vinculados y las relaciones entre ellos, entendiendo que los tanques de agua no son simplemente depósitos de agua. Este estudio multidisciplinar intenta demostrar el concepto de tanques de agua entendidos como ecosistemas, describiendo y analizando de una manera profunda novedosa las funciones, usos, recursos naturales y actores. La investigación se centra también en el análisis de la percepción ecosistémica de la población local de algunas comunidades en Tamil Nadu (India del Sur), empleando diversas metodologías antropológicas.

Palabras clave: tanque de agua, ecosistema, gestión integral, percepción social, India del Sur, participación

\begin{abstract}
Water tanks offer from many centuries ago solutions in South India for several problems related with water scarcity. They are a traditional water harvesting system wide spread in this territory, allowing a potential decentralized and participatory management of the local population on their own resources. Although water tanks' main function is irrigation, they have many other uses, functions and natural resources associated, involving stakeholders in the villages apart from those farmers making use of the irrigation. Water tanks provide a variety of landscapes and biodiversity that creates a valuable heterogeneous territory. The complexity of such an ecosystem should be managed with an integral perspective, considering all the elements involved and their relations, and understanding that water tanks are not just water deposits. This multidisciplinary study tries to demonstrate the idea of water tanks as ecosystems, describing and analyzing deeply and in an
\end{abstract}

\footnotetext{
${ }^{1}$ P.A., E.G., and T.S. designed the approach, collected the data and wrote the article. VR-G supervised the research.

${ }^{2}$ Enviar correspondencia a: watertanksgroup@gmail.com
} 


\section{perifèria}

Número 7, Diciembre 2007

www. periferia. name

unprecedentedly way the functions, uses, natural resources and stakeholders. The research also focuses in the assessment of the ecosystemic perception of the local population of some villages in Tamil Nadu, employing diverse anthropological methodology.

Keywords: water tank, ecosystem, integral management, social perception, South India, participation

\section{I ntroduction}

Water tanks are complex human-made ecosystems involving many natural resources and providing a wide variety of functions. Furthermore, different stakeholders actively use water tank's resources and functions in different ways. The different ecological, social, and economic elements involved in the ecosystem are closely related and dependent on the existence of the water tank. The central presence of the tank gives the essential structure to the territory.

The geography of South India is characterized by the presence of a large number of tanks, making water tank ecosystems one of the most extended ecosystems in this region. Historically, the main function of tanks was to store and distribute water for irrigation purposes, but water tanks provide many resources other than water for irrigation. Water tanks also entail uses and functions other than those related to agriculture. Uses refer to activities that involve human's active utilization and benefit. Function refers to services generated by water tanks independently of the human direct benefit, such as the ecological services. Palanisami $(2000,2001)$, have shown that water tank ecosystems provide multiple uses (agri-uses, non-agriuses as domestic uses). Here, we classify water tanks uses and functions in economic (i.e., agriculture, livestock, fishing,), ecological (i.e., groundwater recharge, prevention of soil erosion and floods), and socio-cultural (i.e., domestic, leisure, festivals). Water tank functions and uses are not independent one from each other and for one element can share socio-cultural, economic and ecological aspects. For example, rice cultivation has both ecological and economic uses. The ecosystemic resilience that water tanks provide in case of disturbances (like droughts or floods) involves the recuperation of the society, the economy and the natural habitats and species. Thus, this ecological function has also an impact in the 


\section{perifèria}

Número 7, Diciembre 2007

www. periferia.name

economy and the society.

In this sub-chapter, we built on the assumption that water tanks are complex ecosystems that require an integral management. The section has two related goals. First, assess people's perceptions of water tanks. Specifically we analyze whether users conceive tanks as a water storage system, or whether they consider them as complex ecosystems with many closely dependent elements. For the empirical study, we use a primary body of data from two villages in a rocky zone area of the Villupuram District (Tamil Nadu).

Examining the social perception of water tanks is important to improve water tank management. If water tanks are perceived and mainly used as an irrigation infrastructure, then political authorities might argue that other forms of irrigation (i.e., groundwater, dams) might substitute water tanks without further consequences for the local population. In contrast, if - as it happens to be the casepeople perceive and use the many functions and resources of water tank ecosystems, then the substitution of water tanks by other forms of irrigation might have severe collateral effects on the local population.

In the first part of this sub-chapter, we use primary and secondary data to explain the water tanks as ecosystems with different resources, functions, uses and the main stakeholders using water tanks. In the second part, we assess how the studied population perceived water tanks.

\section{A. Description of water tanks as ecosystems}

Water tanks provide different habitats creating a heterogeneous net of interconnected territories. Water tank ecosystems include the physic area occupied by the tank, the surrounding spaces, the resources associated with the tank, the human population living in the area, and the connected water bodies. The area occupied by tank changes from rainy to dry season. During the dry season, when the tank is at its lowest, the tank bed becomes a common open land (porombokku) where several natural resources can be found. Occasionally, the tank bed is also (legally or illegally) encroached by some farmers who grow seasonal crops on it. The surrounding spaces of the tank include the agricultural fields, the natural 


\section{perifèria}

Número 7, Diciembre 2007

www.periferia.name

spaces like forests, and the human settlements. Both the natural resources and the human population living around the water tank are key elements of the ecosystem, because they depend on it and continuously modify it. Last, water tanks are linked to an extensive net of water bodies, including small ponds (kulams), wells, other water tanks, and, in some cases, rivers. The net of depending territories and related water bodies amplifies the ecosystemic relations of a water tank to a large scale. Thus, the boundaries of the water tank ecosystem are not limited to the area surrounding the tank, but it has diffuse limits.

\section{Uses and functions of natural resources in water tanks}

Water stored in tanks is the main natural resource associated to them. Historically, water in water tanks was mainly used for agriculture, but also for cattle and as drinking water. Because water tanks ecosystems are formed by several landscapes, many other natural resources - other than water- are associated to water tank ecosystems, increasing the value of the ecosystem from a social and ecological point of view. Here we distinguish between the economic, socio-cultural, and ecologic functions of water tank ecosystems, although we acknowledge that some uses and functions might overlap (Figure 1). 


\section{perifèria}

Número 7, Diciembre 2007

www.periferia.name

\section{Functions and uses scheme}

\section{Economic Functions}

- Development of agriculture

- Insurance against low rainfall periods

- Livestock uses $\leadsto\left\{\begin{array}{l}\bullet \text { Grazing } \\ \cdot \text { Drinking }\end{array}\right.$

- Fishing

- Duck rearing

- Duck rearing
- Building raw materials

- Tree crops

- Auctions - Trees $\left\{\begin{array}{l}\cdot \text { Grass } \\ \cdot \text { Fish }\end{array}\right.$

- Silt collection as fertilizer

- Pottery

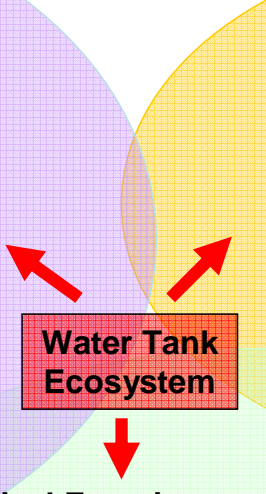

Ecological Functions

-Water conservation

- Soil conservation

- Protection and sustain of the surronding area ecology

- Flood control

- Recharge of groundwater

- Recharge of surface water of other water bodies

\section{Socio-Cultural Functions}

- Ensuring livelihood • Drinking water

- Domestic uses $\rightarrow$ Washing

- Toilet

-Temple festival

- Conservation of traditional knowledge and culture

- Avoid erosion

- Creation of organic layer of silt

- Provision of many habitats

- Conservation of biodiversity

-Well

- Kulam, Oorani, Kuttai, etc.

- Other water tanks

- Kulams

Figure 1. Functions and uses scheme.

Water tank have a clear economic use for villagers, involved or not in irrigation. Most natural resources associated to water tanks are considered village's common property. Villagers exploit natural resources in two different ways so the benefits are shared among the entire village. First, villagers celebrate public auctions to award the exploitation of natural resources of economic importance (i.e., trees, grass) to a single user. The money paid on the auction is commonly used as a fund to the village and is invested for the common benefit (mostly to fund temple festivals), or shared between the members of the village. Second, the exploitation of minor natural resources (i.e., silt for manure or medicinal plants) is open access. Any person from the village can access those resources. For example, the collection of silt from the tank bed to be used as manure for the agricultural lands is open to any villager. In sum, the wide variety of natural resources found in tank 


\section{perifèria}

Número 7, Diciembre 2007

www. periferia. name

ecosystems has an economic use for many people, other than farmers.

Besides its economic uses, water tank ecosystems also provide many social and cultural uses and functions. Water tanks show the footprint of the relation of the Tamil culture with the environment through using it as a sacred place where traditional rituals take place ${ }^{3}$. For example, during some festivals the tank-bed is used as a stage for dramas, and sometimes cattle is sacrificed in the tank. Tanks are also used in parts of the celebration of Hindu weddings and in burial ceremonies. Also related with the preservation of traditional religious rituals, the potter community makes some sacred goddess statues with the soil of the tank. Tanks also have an active role in the preservation of ethnobotanical knowledge, especially medicinal knowledge, because most of the wild medicinal plants are found in the tank's surroundings. Last, other important social use, sometimes not mentioned by the local population but very common, is as a toilet place. Bushes around the water tank provide a hidden and private area and water supply. Women appreciate more than men the privacy of bushes in the water tanks to use them as toilets.

Water tanks are also central in the ecology of the area, providing the necessary ecological functions for a healthy environment. Water tank ecosystems include many types of different habitats, such as lacustrine, cereal cultivated fields, forests, tree plantations, shrub lands, riparian, or urban. Biodiversity of tank ecosystems can potentially be very high. Biodiversity guarantees the necessary functional units to provide and to ensure the supply of environmental services. Conservation of biodiversity is also an ecological insurance for the future that allows the ecosystem to regulate itself to the proper stable environmental conditions. The provision and creation of different habitats and the conservation of biodiversity increments tank ecosystems strength against ecological disturbances, generating high socioecosystemic resilience. The conservation of animal and plant species is a consequence of the ecological functions that tanks provide. Tanks are bird's

\footnotetext{
3 Interviews at study cases and Interview with Raghunatan, Director of Center for Ecology and Rural Development.
} 


\section{perifèria}

Número 7, Diciembre 2007

www. periferia.name

sanctuaries and they help to preserve the avifaunal biodiversity. Tanks are very important for wetland and field birds, but also for migratory birds, which have adapted to use the tanks as a necessary place to rest and eat during their migrations. The dead storage of the tank has also the function to keep alive fish and other aquatic animals in the tank during the dry season.

In sum, water tanks are fundamental to conserve the dynamics of the ecology of the area. As explained before, water tanks are a central part of the territory, supporting and connecting many of its different ecological compartments (i.e., water, biota and soil), and creating a balance between the human actions exploiting the territory and the reposition and rehabilitation of the natural resources and dynamics.

Bellow we describe the natural resources associated to the tank and their main economic, social, and ecologic functions. Previous authors have provided descriptions of the agricultural use of water from water tanks (Mukundan 1988, Janakarajan 1991, Palanisami and Easter 2001, Vaidyanathan 2001, Mosse 2003), so here we only provide a brief description of the resource water and we focus on other six natural resources dependant on the existence of water tank ecosystems: trees, grass, other non-timber plants, fish, other wild animals, and soil.

Water: Historically, the development of tanks in South India is linked to the development of agriculture (Mosse, 2003). South India climate is determined by intense monsoons and severe long dry periods. Agriculture could not have been developed with the current crop production in the area without water tanks. Thus the most salient economic function of water tanks is the storage and provision water for the irrigation of crops. The existence of tanks allows the growth of crops along the year providing a supply of water for irrigation during part of the dry season and recharging the groundwater depending on ground characteristics (Mosse, 2003).

The most evident ecological function of water tanks is to preserve rainwater for periods of drought. Water tanks preserve water in the surface but also recharge groundwater through percolation. Furthermore, water from tanks might recharge 


\section{perifèria}

Número 7, Diciembre 2007

www. periferia. name

other water bodies like other tanks or kulams through channels or groundwater flows.

Another important ecological function of tanks is to prevent floods. The climate characteristics of the area, with very heavy rains during very short periods make all South India a flood-risk area. Historically, water tanks control and protect from floods keeping closed the run-off waters and distributing the surplus water during periods of heavy rains. In case of poor maintenance of water tanks and canals, risk of floods becomes a major problem to the entire population and territory.

Water from tanks has also had a key socio-cultural function: to provide the basic supply of drinking water for the population. Through the history, villagers have used water from the tank and dependent kulams to drink. Water bodies were not polluted with fertilizers and pesticides, thus the water was apt for human consumption. Nowadays most drinking water come from pipping networks, generally supplied in rocky zone with water from a big well constructed inside the tank beds. Pipping networks use the groundwater available from the tanks' recharge. Thus, to this day, drinking water in rural villages of rocky areas is associated to water tanks.

Washing vessels and clothes are other very extended domestic uses of the water in the tank. Women wash vessels directly on the tank, on irrigation canals, wells, or kulams. Villagers also use tanks to wash or refresh cattle, and even to wash vehicles.

Last, bathing in the water tanks is most common when tanks are full of water, at the end of the rainy season. Bathing in the tank does not only have hygienic reasons, but is also done for leisure. When the tank bed is empty of water, there is a flat open space that is used in many cases as a playground for children or to practise sports like cricket.

Trees: A variety of trees are key elements of the water tank ecosystem due to their important uses and functions. Trees may be located almost everywhere in the tank ecosystem, but they mainly grow in the tank's bund, the tank bed, at the edges of agricultural fields, on the streets of the villages, and besides the main roads. The 


\section{perifèria}

Número 7, Diciembre 2007

\section{www.periferia.name}

most important uses of trees are the human consumption of fruits and the use of logs for firewood and timber. For example, in the study area, enormous tamarind trees are commonly found besides the roads and their fruits are consumed locally. Wild trees such as Prosopis juliflora and Acacia nilotica are mainly used as timber and firewood. Fruits like coconuts and palm nuts are also consumed or used to make liquor. The big leaves of the palm trees are used to construct light roofs and walls of the traditional houses in the villages. During the 1960's the Forest Department of Tamil Nadu implemented programs to encourage the growth of fastgrowing tree species inside the tank bed. Following this program, species such as Prosopis juliflora or Acacia nilotica are auctioned and harvested after about 20 years (Palanisami 2001).

Trees also provide important ecological functions such as creating a micro-climate which refresh the temperature of the area, they purify the air, and they are the living place of many animal species.

Grass: Grass is especially abundant in most of water tanks during the dry season, when they occupy most of the tank bed. One of the main species of grass in the water tanks of Tamil Nadu is a perennial grass called Vetiver (Vetiveria zizanioides). Vetiver grows when the surface water on the tank bed empties after the rainy season, leaving an open space in the remaining area. This long and hard grass has important economic uses since it is used as construction material to build the roofs of many houses. It is also fodder for the cattle. Weed infestations and encroachment of the tank bed are now reducing the quantity of grass available. Other type of soft grass also grows on the tank bed. Soft grass is important for the grazing activities of the villagers owning livestock, because it provides fodder for cattle even in the season when no other food is available.

Other non-timber plant species: Bushes and aquatic plants found in water tanks also have different uses and functions. For example, many plants have medicinal properties in the leaves or sap. Some are used for cooking as spices or flavours, to make oils and lubricants or liquid fuels, or even to prepare poisons. Villagers also use bushes as domestic fuel. 


\section{perifèria}

Número 7, Diciembre 2007

\section{www.periferia.name}

Fish: Fish growing in the various water bodies associated to the water tank is an important source of food for villagers. Fishes grow naturally in the different water bodies, although new development programs incite villagers to often introduce them to increase fish production. During the dry season, most of the tanks are emptying of the remaining water, in some cases the villagers empty completely the water of the tank, in order to catch the fishes with ease. The access to fish differs from village to village (free access to all, customary rights for fishermen community who sell them to local markets, right given to the person(s) who took the auction and sell them). Whatever the case, villagers consume fishes.

Other wild animals: In addition to fish, water tank ecosystems are the natural habitat for many other wild animals. The diversity and quantity of fauna vary a lot depending on the area. The tank provides an aquatic ecosystem in a dry and hot area where it creates a proper habitat for many different lacustrine and aquatic animals. Birds like ducks, herons, partridges, and pigeons are important groups of wild animals inhabiting the tank ecosystem. Some villagers may hunt those birds for meat or feathers. Villagers also take the eggs of some species, which are considered as delicatessen. Crabs, snails, and shellfishes are also commonly collected from the tanks and other water bodies like kulams and consumed or used to prepare medicines and manures. Many other types of animals like little mammals, snakes, frogs, and lizards live in the tank ecosystems, and they can be exploited or not by humans depending on the village.

Soil: The soil of the tank ecosystem is also a valuable natural resource for villagers. The natural processes in the tank ecosystem generate several types of soils, being the silt the most important for human uses. Silt has a high value as fertilizer for cultivated lands. Silt is mostly found on the tank bed, in the central part where water accumulates forming a layer of black soil very rich in organic matter and nutrients. The run-off water collects many different materials, such as leaves, branches, and humus, in their way from the catchment area to the tank. Those materials accumulate and decompose on the tank bed, creating a new layer on the land. Villagers collect the silt from the tank, transport it, and spread it in their cultivation fields as fertilizer. Villagers also exploit the red clay from water 


\section{perifèria}

Número 7, Diciembre 2007

www. periferia.name

tank ecosystems to make bricks and tiles. The red clay is available in many tank beds due to its accumulation in stagnant water's areas, collected from catchment areas rich in this material.

By controlling surface water flows, tanks also provide the ecological function of avoiding soil erosion, thus preserving the necessary layers of soil to keep the fertile lands. The creation of a layer of silt on the tank bed and subsequent distribution along the fields by farmers also contributes to create and maintain the quality of soil in the area.

\section{Stakeholders in water tank ecosystems}

Because water tanks involve many resources, uses, and functions, they also affect a variety of groups of users and beneficiaries. Each group has a different interest on the uses, functions and resources of the tank ecosystem, and therefore interacts in a different way with it. Some of the groups have more power than others to manage and make decision that will affect the transformation of the ecosystem. Some groups influence only the ecosystem transformation without being directly involved in the management. Below we describe the different groups of interest found in the area.

The interest of the farmers landholders on the water tank ecosystem depends on the type and surface of land owned. Agricultural lands around tanks are usually classified as irrigated (nanjai) or dry land (punjai). For example, according to the Tamil Nadu Farmers Management of Irrigation Systems Act (TNFMIS) only farmers having nanjai land are legal members of Water Users Associations (WUA) ${ }^{4}$. In practice, not all the nanjai farmers are involved in the management of the tank through this institution. Some rich farmers, well's owners, and encroachers, may not formally participate in the WUA, but they influence water tank management through their influence in village's social life, given that they have a high rank in the local social hierarchies. Farmers having punjai land are not legally involved in the WUA, but they are also important stakeholders in water tank ecosystem,

\footnotetext{
${ }^{4}$ According the TNFMIS, the WUA are the institution that should manage the water tanks. The roles and functions of WUA are explained in chapter 6 of this book.
} 


\section{perifèria}

Número 7, Diciembre 2007

www. periferia.name

because they are groundwater users and potential participants in the auctions of natural resources.

Differences of interest among farmers can also be due to the total surface owned. Big, small, and marginal farmers ${ }^{5}$ occupy different social positions and roles within the society. The social position established by the socio-economical differences (social class) affects the uses and interests about the tank ecosystem of different groups. The big farmers have a greater opportunity to be the highest bidder in the auctions. The marginal farmers and landless people are more dependent on the natural resources in free access offered by the tank ecosystem. Last, the hierarchical structure of the caste system also affects the role and the access to uses and resources of different caste groups as it will be explained in the results.

Landless people constitute a diverse group which have interests on the tank uses, functions, and resources that depart from those of farmers. The agricultural labourers and shepherds are direct users of tanks although they do not own land. As persons working in the fields, agricultural laborers depend on the tank for their daily work, like farmers. Shepherds use the water and the grass for rearing cattle. Some landless people use the grass in the tanks for roofing their house and their stall. Fishermen and duck owners might not use the tank daily, but they do in some seasons. Some nomads often hunt wild animals or fish if there is no auction procedure in the tanks.

There are also some gender differences referring to the uses of the tank ecosystem. Women make more domestic uses, washing clothes and vessels and collecting firewood, apart from their agricultural tasks, as we will see in the results in our study cases.

Finally, the rest of villagers with non-agricultural occupation (shop owners, taxi and lorry drivers, students, road construction workers, tailors, building constructors, teachers, innkeepers, etc.) are also indirect beneficiaries of water tanks. All the residents in a village have water tank benefit from diverse functions

\footnotetext{
${ }^{5}$ The common classification of landholding within administration and economists consider the following criteria: > $5 \mathrm{Ha}$ : big farmers, 2.5-5 Ha: small farmers, <2.5 Ha: marginal farmers.
} 


\section{perifèria}

Número 7, Diciembre 2007

www.periferia.name

of the water tank, recharge of drinking water wells, uses of wells, revenues of the auctions spent in the temple festivals. Villagers also benefit from the many ecological services of water tanks (i.e., prevention of floods). Hence, the entire village benefit from the water tanks in a direct or indirect way.

The complex village society is then, an important element of the tank ecosystem that transforms it through its involvement with the economic and socio-cultural uses, within the net of ecological relations of the tank ecosystem elements.

\section{B- Assessing the ecosystemic perception of the society}

To compare the local perception of water tanks with their current management, we examined whether people perceive water tanks as ecosystems or whether they mainly perceive them as irrigation infrastructures, without understanding the relations of the diverse elements. To do so, we conducted field research in the upper and western part of the Kaluvelli watershed, in the Villupuram district of Tamil Nadu.

\section{I - Methods}

We collected data during a four-month internship with the IFP (Feb-May 2007). Research was conducted in two villages, Endiyur and Attur, both at about five kilometres to the east of the nearest city, Tindivanam. We selected the villages according to six criteria. First, both villages have non-system tanks that belong to the Public Works Department (PWD) and Panchayat Union (PU). Non-system tanks are more dependant on rain water than tanks connected to rivers. Second, both villages are located in a pediplain rocky zone. Wells in rocky zones are less deep than wells in alluvial area due to the hardness of the rocks and the lack of the technology to dig deeper wells. The first two criteria assure that villagers depend on the tank for irrigation, and thus increasing the potential importance of the tank for the villages. Third, in both villages there were functioning Traditional Irrigation Institutions. Fourth, both villages celebrate auctions of natural resources from the water tank. Auctions might influence the importance of the tank for the livelihood and for the potential ecosystemic perception of the local population. Last, villages differ in the presence of modern irrigation institutions (fifth criterion). In Endiyur 


\section{perifèria}

Número 7, Diciembre 2007

www. periferia.name

there were two Water User Association implemented by one NGO (Palmyra) that promotes tank rehabilitation's activities. In Attur there were no modern irrigation institutions implemented. The presence of modern institutions should affect villagers ecosystemic perception of water tanks. The presence of the NGO is another important criterion.

a) The setting

Endiyur is a suburban village with more than 3000 inhabitants in about 665 households (Census of India, 2002). About 95\% of Endiyur's population belongs to the vanniar caste (Most Backward Caste, MBC). The remaining 5\% belong to other MBC castes such as assari, ambattan, and dobi. The main economic activity in Endiyur is agriculture (80\% of the active population) (Suseela et al. 2006). Most of the households in Endiyur (73\%) are formed by small or marginal farmers and only $10 \%$ by big farmers (with more than 5 acres). About 17\% of households in Endiyur do not own any land.

Attur, is a small village with about 1350 inhabitants in 290 households. The village is divided between the Ur and the Colony. In the Ur live the Backward Caste, BC (naidu, 24\%), the Most Backward Castes (vanniar, 37\%), and Other Caste, OC (reddyar and muslim, 4\%). In the Colony live people from the Scheduled Castes (SC) (most of them adi dravidar, 34\%) and some christians, BC (1\%). As in Endiyur the main economic activity in Attur is agriculture. Most of the households belong to small and marginal farmers (58\%), and only $5 \%$ to big farmers, who mostly live in the Ur. About $37 \%$ of the households are landless and most of them live in the Colony.

Both villages have two non-system tanks. The two tanks in Endiyur are called Periya Eri and Chinna Eri, and the two tanks in Attur are called Attur Union Tank and Aranguti Eri. The PWD is responsible for the two big tanks (Periya Eri and Attur Union Tank) and the Panchayat Union for the two small ones (Chinna Eri and Aranguti Eri). At the local level, the institutions involved in the tank management are the nattamais, the village Panchayat, and the nanjai farmers themselves. In Endiyur there are also two WUA, one for each tank. 


\section{perifèria}

Número 7, Diciembre 2007

www. periferia.name

b) Data collection

We collected qualitative and quantitative data. Qualitative data was collected through the research, but mostly during the first month of field work, and contributed to provide a general description of 1 ) the water tank ecosystem and 2) the role of all the stakeholders and institutions involved in the use and management of the tank ecosystem. Methods of qualitative data collection used for a ecosystemic description include participant observation, participatory rural appraisal (PRA), open-ended interviews with key informants, and a qualitative environmental diagnosis.

To assess the local perception of water tanks, we collected quantitative data using free listings, pile sorts, and knowledge and use tests. We conducted free listings to generate a comprehensive list of local functions of water tanks (Weller 1998). The free listing method consists in generating lists of elements that are related with a cultural domain. In our case the objective of the free listing was to get a list of the tank ecosystem domain formed by all its resources, uses, and functions. We used free listings in both villages with a stratified sample of 54 people that included the various groups with expected variation in the perception about the water tank ecosystem, such as men and women or people with different types of occupation and land. Every person was asked "Why do you think the water tank is important for the village?". We selected some items from the results and added some other elements from the literature and from the qualitative data collection, to elaborate cards with drawings representing village's elements. We prepared 28 items cards (see Fig\# 7.3) to conduct the pile sort method. Pile sorts are used to assess the relations that people make among the different elements of the water tank ecosystem. We asked a total of 44 people drawn from a stratified sample in each village to sort the pictures in piles according to their similarities (Bernard 1995).

To better understand differences in people's knowledge of tank ecosystems, and to check if knowledge relates with daily activities and uses, we carried out a knowledge and use test. This method was useful to understand the differences between different stakeholders. We asked a stratified sample of informants 


\section{perifèria}

Número 7, Diciembre 2007

www. periferia. name

$(n=109)$ to answer 11 theoretical questions about the resources and functions of the tank, seven questions about their use of water tank resources and functions, and two questions about water tank management. Theoretical questions included questions that aimed at assessing informant's perception of the ecosystemic nature of tanks, such as, ecological functions of the trees in the bund. Thus a higher score in this part indicates higher knowledge of the ecosystemic nature of the tank. The questionnaire about the use of the water tank included a set of questions on the many possible uses of tanks, such as washing clothes and using silt from the tank as manure. Thus, a higher score in the practical part indicates more diverse uses of the tank's resources and functions. The management part included opinion questions about who should be in charge of managing the water tanks. All the questions were in a multiple-choice format. People's answers were classified according their high or low knowledge or use about water tanks having a numeric mark in each question. To analyze responses we generated two different scores adding the correct responses to each part of the questionnaire, one for the knowledge questions and one for the use questions.

To analyze the data collected through freelisting, we calculated: 1) The frequency measures the people who told each item; 2) The average rank of how each item was on average ordered in the list of respondents; and 3) a Saliency index that takes into account at the same time the frequency and the average rank of the element in the respondents list. The Saliency Index evaluates the importance of an item in the all the lists (see Table \#7.1). To analyze data from pile sort, we use non-metric multidimensional scaling to create a chart (see Figure \#7.2) with clusters of elements. To analyze responses to knowledge and use test, we did two analyses. One was to analyze each single question because to answer correctly one question meant to have specific knowledge about one ecosystemic relation. The other one was to sum for each individual the marks of the questions of each part of the questionnaire to get a mean to compare different groups. To analyze the knowledge and use scores, we used t-test and chi-square test. 


\section{perifèria}

Número 7, Diciembre 2007

www.periferia.name

\section{II-Results of the study: Local perception of tank ecosystem}

In the freelisting exercise, informants listed a total of 51 different reasons why water tanks are important for the village. On average each informant listed eight items in free listing $(S D=3)$ The shortest list had two items and the longest 17. None of the respondents mentioned only the purpose of storing water, which can be interpreted as that nobody would think that the tank is a device with the only purpose to store water. The length and diversity of items in the lists are the first indicators that people do recognize many of the different uses and functions of water tanks.

The maintenance of crops was single out as the most important and salient item in our lists. $80 \%$ of the people interviewed mentioned crops, and on average crops were mentioned as the second item in free listing (Table 1). But although crops was the most important item in free listing, it is worth mentioning that as much as $20 \%$ of the people interviewed did not mention crops when being asked to list the reasons why water tanks are important for the village. If we put together "crops" and "irrigation", we still find that as much as $7 \%$ of the people interviewed did not mention any of these two uses.

Among the 15 more salient items we can find ten direct utilitarian functions of the tank, eight economic, social and ecological uses of water, and seven natural resources and their uses. We highlight here the high saliency of two elements not related with agriculture: fish and drinking water.

We run the same data using only parts of the sample. We found that using trees as firewood and washing clothes were more salient for women than for men in the sample. The people with occupations related with agriculture mentioned more "recharge of wells" and less "drinking water" and "fish" than people working in other occupations. For landless people "drinking water for the cattle" and the "grass for the roofs" were more salient than for landholders, who in turn give more saliency to "irrigation" and "auctions". Finally the farmers having nanjai land sorted as more important the "silt used as manure" and "recharge of wells" than farmers with punjai land. 


\section{perifèria}

Número 7, Diciembre 2007

www.periferia.name

\begin{tabular}{lccccc}
\hline & I tem & Frequency & $\%$ & Avg. rank & Saliency \\
\hline 1 & Crops & 43 & 80 & 2.093 & 0.700 \\
2 & I rrigation & 25 & 46 & 2.840 & 0.377 \\
3 & Drinking water for cattle & 29 & 54 & 3.759 & 0.372 \\
4 & Fish & 33 & 61 & 5.515 & 0.285 \\
5 & Drinking water & 23 & 43 & 3.826 & 0.283 \\
6 & Recharge of wells & 20 & 37 & 3.700 & 0.260 \\
7 & Water storage device & 14 & 26 & 3.000 & 0.190 \\
8 & To wash clothes & 19 & 35 & 6.211 & 0.175 \\
9 & Grass to make roofs & 15 & 28 & 4.933 & 0.172 \\
10 & Trees & 21 & 39 & 6.000 & 0.168 \\
11 & Grass & 16 & 30 & 5.500 & 0.150 \\
12 & Firewood & 16 & 30 & 6.438 & 0.135 \\
13 & Bathing & 15 & 28 & 6.333 & 0.128 \\
14 & Silt used as manure & 14 & 26 & 6.929 & 0.111 \\
15 & Auction of fish & 14 & 26 & 7.143 & 0.102 \\
\hline
\end{tabular}

Table 1. General results of the 15 first elements from the free listing sorted by Saliency $(n=51)$.

Results from pile sorting concur with results from free listings. Figure 2 shows results from a non-metric multidimensional scaling with pile sort data from informants in the two communities. The clusters should be interpreted as elements related among them by the informants. Most resources and functions appear clustered on the left-hand side of the graphic and related to water tank, meaning that informants associated those different uses together with ecological relations among them.

There are three main clusters. One cluster relates to the water tank. A second cluster constitutes a household or domestic group (man, woman and house), and the third cluster relates to management (government, nattamai and festival). The tank is situated as the central element in the main wide group of related elements (see Fig 2, marked with light blue filled circle). The graph suggest that villagers demonstrate knowledge about some ecological relations like recharging wells, strengthening the bund with trees, processes linked to the quality of water, or knowing the best location to take silt from the tank bed. 


\section{perifèria}

Número 7, Diciembre 2007

www. periferia. name

Inside this wide cluster, we can find several subgroup. One group includes way of water (canals, rain, flood, crops, supply channels (odais), groundwater recharge, wells, etc.). Another group includes elements related to groundwater (formed by drinking water, wells and kulams). And a third group includes natural resources found in the eri (grass, fish, silts, trees) and uses like washing clothes and the cattle rearing.

Items that in the graph appear close to the tank are elements that are located physically in the tank or direct related uses. Items that in the graph appear far from the tank group are those elements with a higher abstract and indirect relation with the tank. There are some elements that are between two domains in the people's perception (auctions and firewood). 


\section{perifèria}

Número 7, Diciembre 2007

www.periferia.name

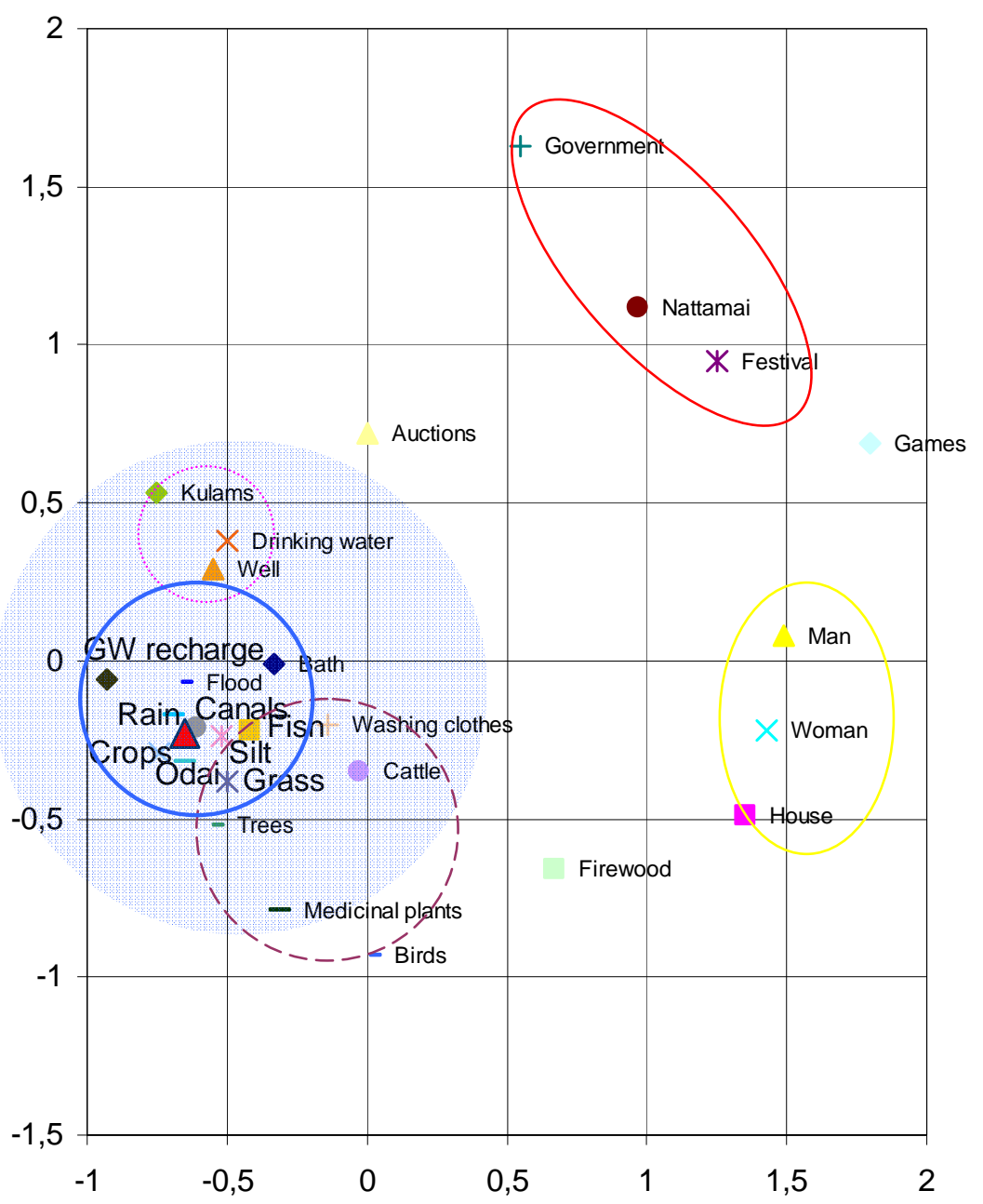

- Bath

- House

Man

$\times$ Woman

* Festival

- Nattamai

+ Government

- Flood

- Rain

Games

Firewood

Auctions

Crops

* Silt

Cattle

+ Washing clothes

- Birds

- Odai

Kulams

Fish

$\triangle$ Well

$\times$ Drinking water

* Grass

Canals

$\triangle \mathrm{ERI}$

- Trees

- Medicinal plants

- GW recharge

Figure 2. Multidimensional scaling of pile sort exercise.

Three main domains are highlighted: 1) water tank group (circle filled in light grey): with three subgroups: Groundwater (points circle); Way of water (dark grey continuous circle); General uses (lines circle); 2)Households or domestic group; 3) Management at the elite level.

We used results from the 'knowledge and use test' to assess the correspondence between knowledge and use of the water tank ecosystem by the villagers. We found a positive and statistically significant correlation between individual knowledge and use scores. Results from a Pearson correlation between individual 


\section{perifèria}

Número 7, Diciembre 2007

www. periferia. name

knowledge and use scores had a coefficient of $0.34(p=0.0003 ; n=109)$. The low correlation coefficient can be due to recent changes in some practices, such as the use of artificial fertilizers. For example, we found that the $80 \%$ of the people related with agriculture know where is the better place to take silt to use as manure (near the sluice, located in the bund), but only the $48 \%$ of the farmers really use this resource from the tank. This means that when there are low values of correspondence between knowledge and use shown by the villagers, they are in general related to external factors outside the villagers' control. These external factors are mainly related to economic decisions, when there is not competition for the external alternatives of use and resources away from the tank ecosystem, like the artificial fertilizers instead of using silt as manure.

Beyond to provide a tool to check the correspondence between the knowledge and use, the knowledge and use test was also useful to get some results about the differences among groups.

We also analyzed differences in knowledge and use scores according to individual attributes (Table 2). We found that farmers and agricultural labourers had a higher knowledge score (mean=18.2) than people with other occupations (mean=14.6). The difference of means between the two occupational groups was statistically significant $(p<0.1)$. We also found that landowners, nanjai farmers, people who had received training or participated in some schemes like NREGA, and people who have undertaken management duties at whatever level had significantly higher knowledge scores than people without those characteristics. When dividing the population according to their sex, we found that men had significant higher scores than women. Analyzing the data according the caste of the respondents we did not find significant differences in the knowledge among the scheduled caste people and the other caste groups. 


\section{perifèria}

Número 7, Diciembre 2007

www.periferia.name

\begin{tabular}{|c|c|c|c|c|c|c|c|c|c|}
\hline & & Mean & SD & Obs & & Mean & SD & Obs & $\begin{array}{c}\text { T-Test of } \\
\text { comparisons } \\
\text { of means }(p)\end{array}$ \\
\hline Occupation & $\begin{array}{c}\text { Farmers and } \\
\text { agricultural } \\
\text { labourers }\end{array}$ & 18.2 & 3.9 & 74 & $\begin{array}{c}\text { Other } \\
\text { occupatio } \\
\text { ns }\end{array}$ & 14.6 & 3.9 & 35 & 0.000 \\
\hline $\begin{array}{l}\text { Land } \\
\text { ownership }\end{array}$ & Land owners & 18.1 & 3.9 & 75 & Landless & 14.7 & 4.0 & 34 & .0001 \\
\hline $\begin{array}{l}\text { Type of } \\
\text { landholding }\end{array}$ & $\begin{array}{c}\text { Nanjai } \\
\text { farmers }\end{array}$ & 18.8 & 3.9 & 46 & $\begin{array}{l}\text { Punjai } \\
\text { farmers }\end{array}$ & 15.8 & 4.0 & 63 & 0.0001 \\
\hline Training & $\begin{array}{l}\text { Have } \\
\text { received } \\
\text { training }\end{array}$ & 20.0 & 4.3 & 17 & $\begin{array}{l}\text { No } \\
\text { training }\end{array}$ & 16.5 & 4.0 & 92 & .0011 \\
\hline Participation* & Yes & 18.7 & 4.5 & 59 & No & 16.4 & 3.9 & 37 & 0.007 \\
\hline Gender & Male & 17.8 & 4.1 & 48 & Female & 16.5 & 4.3 & 61 & 0.05 \\
\hline Caste & $\begin{array}{l}\text { Scheduled } \\
\text { caste }\end{array}$ & 18.2 & 4.4 & 19 & $\begin{array}{l}\text { Other } \\
\text { castes }\end{array}$ & 17.2 & 4.3 & 77 & 0.33 \\
\hline
\end{tabular}

Note1: * Participation refers to people who report having been involved in tank management duties at whatever level (Panchayat, Gramma sabha, SHG, NGOs, and WUA) and in some schemes (NREGA). Nanjai includes the farmers having nanjai land and farmers having nanjai and punjai lands. The punjai farmers category includes the people who only have punjai land.

Table 2. Comparison of Mean of Knowledge Scores in Tests of Multiple Choice in different groups.

We conducted a similar analysis for use scores. Recall that the scores of use do not relate to a higher intensity of uses, but a higher diversity of uses. We did not find significant differences in use scores associated to individual socio-economic characteristics (see Table 3). Most of the groups in the sample have similar scores in the questionnaire about the use of the water tank, regardless of their occupation, land ownership, type of landholding, training in water tanks, and gender with one exception. When dividing the population according to caste, we found that people who belong to a scheduled caste had significantly higher diversity of uses of the water tanks than the people who belong to other casts $(p=0.03)$. 


\section{perifèria}

Número 7, Diciembre 2007

www. periferia. name

\begin{tabular}{|c|c|c|c|c|c|c|c|c|c|}
\hline & & Mean & SD & Obs & & Mean & SD & Obs & $\begin{array}{l}\text { T-Test of } \\
\text { comparisons } \\
\text { of means }(p)\end{array}$ \\
\hline Occupation & $\begin{array}{l}\text { Farmers and } \\
\text { agricultural } \\
\text { labourers }\end{array}$ & 3.9 & 2.3 & 74 & $\begin{array}{c}\text { Other } \\
\text { occupations }\end{array}$ & 3.4 & 2.4 & 35 & 0.12 \\
\hline $\begin{array}{c}\text { Land } \\
\text { ownership }\end{array}$ & Land owners & 3.5 & 2.2 & 34 & Landless & 3.8 & 2.4 & 75 & 0.28 \\
\hline $\begin{array}{c}\text { Type of } \\
\text { landholding }\end{array}$ & $\begin{array}{c}\text { Nanjai } \\
\text { farmers* }\end{array}$ & 4 & 2.4 & 46 & $\begin{array}{l}\text { Punjai } \\
\text { farmers }\end{array}$ & 3.6 & 2.2 & 63 & 0.20 \\
\hline Training & $\begin{array}{l}\text { Have received } \\
\text { training }\end{array}$ & 3.3 & 2.7 & 17 & No training & 3.8 & 2.2 & 92 & 0.20 \\
\hline Participation & Yes & 2.3 & 1.4 & 59 & No & 2.3 & 1.3 & 37 & 0.36 \\
\hline Gender & Male & 4.1 & 2.1 & 48 & Female & 3.5 & 2.4 & 61 & 0.10 \\
\hline Caste & $\begin{array}{l}\text { Scheduled } \\
\text { caste }\end{array}$ & 2.7 & 1.3 & 19 & Other castes & 2.1 & 1.3 & 77 & 0.03 \\
\hline
\end{tabular}

Table 3. Comparison of Mean of Use Scores in Tests of Multiple Choice in different groups.

Discussion

In the following section we discuss the general results for the entire population and the results by categories about the ecosystemic perception of the people.

We want to start by saying that the evaluation of such an abstract concept as the perception (or awareness) of the ecosystemic nature of water tanks is a difficult task. Results from our three surveys suggest that people do have an integrated perception about the ecosystem, although we set the factors that determine the differences between groups of people.

Bellow we outline the factors that determine the differences of perception among social groups.

We found that respondents' occupation is related to people's perception of the ecosystemic nature of water tanks. Villagers working with agriculture (farmers and agricultural labourers) have a higher ecosystemic perception of the water tank than villagers who do not work in agriculture. The finding can be explained due to the experience in the field in contact with elements of tank ecosystem. For example, people with agricultural occupation know more and have a better understanding about the ecological relations between the environmental compartments, as the concept of "water quality" asked in the first question of the knowledge test shows. 


\section{perifèria}

Número 7, Diciembre 2007

www. periferia. name

Thus, $50 \%$ of people working in agriculture could explain that nutrients dissolved in water are different depending on the source of water, while only the $25 \%$ of people with other occupation knew it. Similarly, more farmers and agricultural labourers could also explain the ecological functions of the dead storage ${ }^{6} .34 \%$ of people working in agriculture mentioned that the dead storage was useful to recharge wells versus $11 \%$ of people with other occupations. We also found differences related to the occupation of the informants on the knowledge about the best place to take silt from the water tank, and the knowledge and participation in the auctions of natural resources. $89 \%$ of farmers and agricultural labourers knew the location of silt versus $58 \%$ of the people with other occupations. Farmers and agriculture labourers know also the procedure of the auctions, having a more active participation (offering a higher bid), than people with other occupations. Performing cross tabs and Chi-square test we find a significant difference between these two different groups of occupation.

Results from tables 2 and 3 show that, among the people who are dedicated to agriculture, landowners have a more integrated perception of the water tank ecosystem than landless agricultural labourers. The finding can be explained due to landowners' social position and role in management activities. Furthermore, among landowners, nanjai farmers show a higher holistic vision than punjai farmers. The difference can be due to the closer relation of nanjai farmers with the tank through the use of its surface water. For example, when examining the question on the silt location, we found that $100 \%$ of nanjai farmers knew the best place to take the silt. We found a significant difference performing cross tabs and Chi-square test.

We also found that participation and training influence the social perception of water tanks as ecosystems. People who have been trained by some NGO have a more ecosystemic perception of water tanks than people who have not received such training. People who had carried out management duties at whatever level (Panchayat, Self Help Group managing, WUA, financial duties or agricultural managing, for example), were able to make more complex relations of different

\footnotetext{
${ }^{6}$ Water stored in the tank below the sluice level that can not be used for irrigation.
} 


\section{perifèria}

Número 7, Diciembre 2007

www. periferia. name

elements. This eases their perception of the elements of the ecosystem and their relations. For example, $73 \%$ of the people experienced in management activities or trained by NGOs knew the ecological functions of trees located on the bund, but only $35 \%$ of the non-experienced people knew it. There is a significant difference between these two groups when performing cross tabs and Chi-square test. We can see also the same result in the whole analysis of the knowledge scores (see Table 2 ), where it is found the significant difference in knowledge among the people who participate in managing activities or have been trained by some NGOs and other institutions.

We also found gendered differences in tank ecosystem perception. Women use different resources and services of the water tank than men due to the gender domestic labour divison. Services used by women include washing clothes and collection of medicinal plants and firewood. Women's different perception is shown in the free-listing exercise where those items are more salient in women's than in men's freelisting. Men are typically in charge of the management tasks, and this is the reason why we did not find significant differences when analyzing the quantity of uses in the uses test score by gender. The management task done by men creates a more holistic vision of the ecosystem in general, and this is shown in the significant differences in the knowledge scores.

Despite important differences in people's knowledge according to socio-economic characteristics, we did not find differences in the diversity of people's uses of the tank. The finding can be interpreted as that although uses change from one group to another, everybody in the village use the tank for some reason (irrigation, auctions participation, collection of silt and medicinal plants, consumption of natural resources, washing clothes, bathing, drinking cattle or roofing with grass). This important finding contributes to consider the relevance of the water tank functioning as ecosystem and the need of an integrated management considering all the resources, uses, functions and stakeholders. 


\section{perifèria}

Número 7, Diciembre 2007

www. periferia.name

\section{Conclusions}

The ecosystemic approach to the water tank system allows the consideration of all the resources, uses, functions, and stakeholders related to water tanks. The proposed approach enhances the value of water tanks serving the population and giving the essential structure to the territory. This vision suggests that water tanks are irreplaceable by other irrigation sources. As we have shown, the beneficiaries of water tanks uses, resources, and functions are more than WUA's members.. We have analyzed how different groups of stakeholders perceive and use water tanks, and the socio-economic attributes that are associated to those perceptions. We found that knowledge of water tanks varies across socio-economic groups, however, we found that all the respondents use the tank differently but with similar intensity. The finding has implications in the water tank's management. A possible explanation for the serious deficiencies of the current management of water tanks relates to the exclusion in the participation in the management of a large number of stakeholders, a problem which will not be solved with the concept of the WUA implemented in Tamil Nadu.

Finally, it is pertinent to note that an integral management of the entire water tank ecosystem is a reason and a requirement for a "decentralized and participatory management policy", as the higher level institutions (i.e., the World Bank and the State and Central Governments of India) pretend theoretically with their current policies. A decentralized management can be only achieved by considering tanks as ecosystems and their multiple services, and by including the local population in the tank management. The integrated management of tank ecosystems becomes also a requirement for an integrated approach in the watershed management scale. It is necessary to manage integrally the watershed to have a suitable integral management of each water tank ecosystem at local level. In this sense, it is very important to consider the cooperation between villages within a cascade connection of their tanks in a context of decentralized but coordinated management. 


\section{perifèria}

Número 7, Diciembre 2007

www. periferia.name

\section{References}

Agarwal, B. (2001). "Participatory Exclusions, Community Forestry, and Gender: An Analysis for South Asia and a Conceptual Framework". World Development. Vol.29, No. 10, pp. 1623-1648.

Bernard, H. Russell. (1995). Research Methods in Anthropology. Qualitative and Quantitative Approaches. Walnut Creek: Altamira Press.

Census of India. (1995). Census of India 1991, Tamil Nadu, Delhi: Office of the Registrar General.

Census of India. (2002). Census Info India 2001 v.1, CD format. Delhi: Registrar General and Census Commissioner.

FERAL (Foundation for Ecological Research, Advocacy and Learning) (2005). Resource handbook. Planning and monitoring collective local resource management in the Kalivelli watershed. Pondicherry: Foundation for Ecological Research, Advocacy and Learning.

Funtowicz, S. and Ravetz, J. (2000). La Ciencia Posnormal. Ciencia con la gente. First Edition, Barcelona (Spain), Icaria, May.

India, National Rural Employment Guarantee Act (2005). The Gazzette of India. New Delhi, September 7 , Number 42

India. Tamil Nadu Farmers' Management of irrigation systems Act 2000, Act 7 of 2001, Tamil Nadu Government Gazzette, March the 5 of 2001, Num. 178, p. 22

Janakarajan, S. (1991). Working Paper No. 97. In search of Tanks: Some Hidden Facts. Madras: Madras Institute of Development Studies, January.

Mosse, D. (2003). The rule of water. Statecraft, Ecology and Collective Action in South India. New Delhi: Oxford University Press.

Mukundan, T. M. (1998). "The Ery Systems of South INDIA". PPST Bulletin Num.16.

Palanisami, K. and EASTER, W. (2000). Tank irrigation in the 21st Century What next?, first published, New Delhi: Discovery Publishing House.

Palanisami. K, et al. (2001). Sustainability of tank irrigation systems in South India. Coimbatore (India): Water Technology Centre Tamil Nadu Agricultural University, Coimbatore.

Suseela,P, Sobhana, D, Chandra, K.D. Field work report (from 25.02.06 to 18.03.06) of Endiyur. Tamil Nadu., M.A.Sustainable Development, First Year, Pondicherry University.

Vaidyanathan, A. Tanks of South India. Delhi: Centre for Science and Environment. 2001.

Weller, Susan (1998). Structured interviewing and questionnaire construction. In The Handbook of Methods in Cultural Anthropology, edited by Bernard, H. Russell (Walnut Creek: Altamira Press). 